\title{
Arthroscopic thermal capsular shrinkage: a successful treatment option for patients with chronic lateral ankle instability?
}

\author{
J White ${ }^{1 *}$, A Zubairy $^{2}$, M Hakimi $^{2}$ \\ From International Conference for Healthcare and Medical Students 2011 \\ Dublin, Ireland. 4-5 November 2011
}

\section{Introduction}

Thermal capsular shrinkage is a well recognised procedure in the management of shoulder instability, but little data has been collected with regards to other joints. This surgical technique offers an alternative treatment to ligament reconstruction in chronic lateral ankle instability.

\section{Objectives}

This study looks at the outcomes of thermal capsular shrinkage in patients with chronic lateral ankle instability. It aims to audit the results of thermal capsular shrinkage against published literature, and to devise a recommended rehabilitation protocol.

\section{Methods}

Data was collected from 26 patients (12 males, 12 right ankles, mean age 32.88 years) from November 2004 to March 2011. 20 patients were available for follow up. Preoperative MRI scans and stress radiographs were taken. The patients were all assessed using the American Orthopaedic Foot and Ankle Society (AOFAS) anklehindfoot scale, Manchester-Oxford Foot Questionnaire, EuroQol and the Visual Analogue Scale Foot and Ankle. Reviews were held at an average of 27.4 months postoperatively.

\section{Results}

Postoperative AOFAS scores improved by a mean of 40 points $(\mathrm{P}<0.05) .12$ patients rated their satisfaction as excellent or very good, 7 as good and 1 as poor. No revision procedures were required. Physiotherapy regimes

${ }^{1}$ University of Manchester, UK

Full list of author information is available at the end of the article were analysed, and then collaborated to form what we believe to be the optimum postoperative management for these patients.

\section{Conclusions}

Results show that this minimally invasive arthroscopic surgical technique is a successful treatment option with minimal morbidity for patients with chronic lateral ankle instability. No revision procedures were performed.

\section{Author details}

${ }^{1}$ University of Manchester, UK. ${ }^{2}$ East Lancashire Hospitals Trust, UK.

Published: 9 July 2012

doi:10.1186/1753-6561-6-S4-032

Cite this article as: White et al:: Arthroscopic thermal capsular shrinkage: a successful treatment option for patients with chronic lateral ankle instability? BMC Proceedings 2012 6(Suppl 4):O32.

Submit your next manuscript to BioMed Central and take full advantage of:

- Convenient online submission

- Thorough peer review

- No space constraints or color figure charges

- Immediate publication on acceptance

- Inclusion in PubMed, CAS, Scopus and Google Scholar

- Research which is freely available for redistribution

\section{Biomed Central}

(c) 2012 White et al; licensee BioMed Central Ltd. This is an Open Access article distributed under the terms of the Creative Commons Attribution License (http://creativecommons.org/licenses/by/2.0), which permits unrestricted use, distribution, and reproduction in any medium, provided the original work is properly cited. 